\title{
Response of dissolved organic carbon in a shallow groundwater ecosystem to a simulated global warming experiment
}

\author{
K. P. Wilson \& D. D. Williams \\ Department of Life Sciences, \\ University of Toronto at Scarborough, Canada
}

\begin{abstract}
Dissolved organic carbon (DOC) in marine and freshwater ecosystems represents an immense reservoir of organic matter with varied and significant ecological value. Global warming poses a significant threat in that it has the capacity to alter the concentration and distribution of DOC. Since groundwater constitutes approximately two-thirds of the available freshwater on earth, it is crucial to determine how global warming may affect its DOC balance. However, in higher latitudes carbon cycling is poorly understood, and ecosystem-scale studies are urgently required. We conducted an in situ temperature manipulation of a shallow groundwater system in Ontario, Canada that simulated temperature increases predicted by general circulation models for this region. Specifically, treatment block temperatures in spring, summer, and fall were elevated $3.9 \pm 0.6$ $\mathrm{SD}{ }^{\circ} \mathrm{C}$, whereas winter temperatures were elevated $5.0 \pm 0.6{ }^{\circ} \mathrm{C}$ compared with a control block. We found no significant difference in DOC between control and treatment blocks during the pre-manipulation study period. However, there was a significant increase in DOC with groundwater depth in both blocks: $4.54 \pm$ $0.25 \mathrm{mg} / \mathrm{l}$ at $-20 \mathrm{~cm}$ to $5.79 \pm 0.24 \mathrm{mg} / \mathrm{l}$ at $-100 \mathrm{~cm}$. During this period there was also a difference in DOC among seasons: fall and winter concentrations were lower than spring and summer. During the manipulation period there was also no difference in DOC between the control and treatment blocks, however, a positive trend in the treatment block was observed for all collections. Also, seasonal and depth differences between blocks were still apparent. Although during the manipulation period nitrate and total phosphorus showed no difference between control and treatment blocks, ammonia showed a significant decrease in the treatment block. We discuss the implications of these findings to the biogeochemistry and ecology of shallow aquifers.
\end{abstract}

Keywords: global warming, dissolved organic carbon, DOC, shallow groundwater, Canada, temperature manipulation, ecosystem experiment. 


\section{Introduction}

The importance of dissolved organic carbon (DOC) as a potential source of carbon and energy for subsurface and surface metabolism has been widely studied. Fisher and Likens [1] first examined how subsurface waters can effectively transport DOC from terrestrial ecosystems to stream ecosystems. Hynes [2] showed that subsurface DOC contributes significantly to stream ecosystem metabolism. These influences of DOC are due to its ability to affect a variety of physical, chemical, and biological processes. DOC entering shallow groundwater can be from terrestrial environments via soils (Chappelle [3]), through streams via the hyporheic zone (Williams and Hynes [4]), or laterally from riparian zones (Meyer and Tate [5], Storey et al. [6]). Once DOC enters shallow groundwater ecosystems, it can be oxidized to $\mathrm{CO}_{2}$ (Chappelle [3]), or if consisting of labile substances it can be rapidly utilized by microorganisms (Wetzel [7], Storey et al. [6]). DOC interacts with dissolved nutrients influencing nutrient concentrations and can also act as a buffer by affecting $\mathrm{pH}$ (Pace and Cole [8]). There is growing concern of the fate of DOC in higher latitudes because these temperate regions are expected to respond to global warming more so than lower latitudes (Schindler [9]).

General circulation models (GCM) predict increases in temperature to vary between 1.5 and $5.0{ }^{\circ} \mathrm{C}$ by the year 2040 for southern Ontario, Canada (Hengeveld [10]). These models also project a differentially higher temperature increase in winter than in summer in latitudes $>30^{\circ}$ (Hengeveld [10]). Temperature is one of the most important factors that affect life history characteristics and distributions of bacteria (Chapelle [3]) and aquatic insects (Sweeney [11], Vannote and Sweeney [12]). General circulation models have also shown that increased $\mathrm{CO}_{2}$ will change precipitation and temperature patterns, and therefore likely impact the abundance and distribution of species (McCarty [13]). Changes in the community structures of shallow groundwater ecosystems may affect DOC concentrations through changes in metabolic activity and hence aspects of the global carbon-cycle.

Global warming studies examining DOC concentrations have been conducted mainly in terrestrial ecosystems, such as soils (MacDonald et al. [14]), bogs and fens (Pastor et al. [15]), and arctic tundra and sedge ecosystems (Neff and Hooper [16]). Some aquatic ecosystem studies have also examined the response of DOC to global warming and climate change. For example, Schindler et al. [17] examined the physicochemical properties of boreal lakes, with emphasis on DOC and Clair et al. [18] modelled DOC loss from a small temperate wetland under a doubling of $\mathrm{CO}_{2}$. To our knowledge there has not been any direct wholeecosystem manipulation of a shallow groundwater ecosystem that has examined DOC concentrations both spatially and temporally. To address the possible effects of global warming on DOC concentrations in a shallow groundwater ecosystem, we conducted an in situ temperature manipulation of a shallow groundwater ecosystem in accordance with global warming projections for southern Ontario, Canada. Specifically, we examined DOC concentrations: 1) spatially along a natural vertical gradient from surface water to $-100 \mathrm{~cm}$ 
sediment depths; 2) temporally by comparing seasons; and 3) by perturbing the groundwater temperature over a period of 13 months. We predict two possible responses of DOC concentrations to our ecosystem manipulation: 1) DOC concentrations will not change between control and treatment blocks (ambient DOC concentrations maintained by soil C storage); or 2) DOC concentrations will decrease in the treatment block compared with the control block (consumption of DOC through increased metabolism).

\section{Methods and materials}

\subsection{Study site}

This study was conducted on a small first order spring-brook (Valley Spring) located in southern Ontario, Canada $\left(43^{\circ} 45^{\prime} \mathrm{N}, 79^{\circ} 15^{\prime} \mathrm{W}\right)$. Valley Spring is located at an elevation of $152 \mathrm{~m}$ and is approximately $60 \mathrm{~m}$ in length and 0.5 $1.5 \mathrm{~m}$ wide with a discharge ranging between $1800-2300 \mathrm{l} / \mathrm{hr}$. The surrounding vegetation consists of coniferous and deciduous trees and mixed grasses and shrubs. For further descriptions see Williams and Hogg [19] and Hogg and Williams [20].

\subsection{Temperature manipulation}

The temperature manipulation study area was located approximately $5 \mathrm{~m}$ from the spring source in an $8 \mathrm{~m} \times 4 \mathrm{~m}$ grid. The study area was separated into a control and experimental treatment block, each $4 \mathrm{~m} \mathrm{x} 4 \mathrm{~m}$. Heating pipes were installed on 8 October 2003. Eight pipes (110 cm long, $4 \mathrm{~cm}$ outer diameter) pinched at the bottom (last $5 \mathrm{~cm}$ ), were placed at $0.5 \mathrm{~m}$ intervals perpendicular to the stream channel along four transects at $1 \mathrm{~m}$ intervals longitudinally with the stream channel $(n=32$ for each of the control and treatment blocks, fig. 1$)$. A treatment divide $(5 \mathrm{~m}$ in length and $1 \mathrm{~m}$ deep) was installed along a natural groundwater divide in October 2003 using sixteen gauge galvanized steel sheet metal.

To increase the temperature in the treatment block, a $61 \mathrm{~m}$ long EASYHEAT ${ }^{\circledR}$ roof and gutter de-icing cable (Model ADKS, $120 \mathrm{~V}, 1000 \mathrm{~W}$ ) was installed along each transect $(n=4)$. Starting at the end of each cable, $6 \mathrm{~m}$ of cable was wrapped length wise and tied together with cable-ties and placed into each pipe with the lead end running to the next pipe (in series). In order to control seasonal temperatures, each cable was attached to a variable transformer Powerestat ${ }^{\circledR}$ model \# 3PN117C, 120 V, 12 A. Heat was applied on 5 March 2004 and continued until 5 May 2005. From general circulation models our targeted temperature differences between the control and treatment blocks for summer, spring, and fall range from $3.5-4.5^{\circ} \mathrm{C}$ and in winter from $5-6^{\circ} \mathrm{C}$.

\subsection{Collecting regime}

Bimonthly samples of DOC concentrations, nutrients, and water chemistry were collected in June, August, October, December 2002, and February, April, June, 
August, October, and December 2003 and 2004, and February, and April, 2005 ( $\mathrm{n}=18$ collection dates). Collections between June 2002 and February 2004 $(n=11)$ were used to generate pre-manipulation data to determine if there were differences between the control and treatment blocks. Collections between April 2004 and April $2005(n=7)$ were used as manipulation response samples to examine possible temperature effects on DOC concentrations.

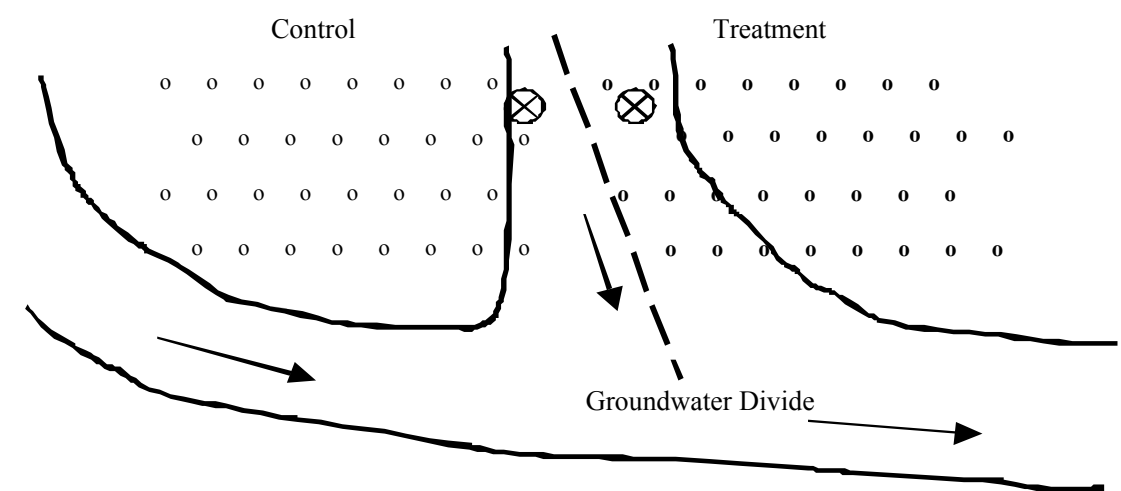

Figure 1: Schematic of experimental design showing the control block (no heat) and treatment block (heating). Bold circles (o) represent heating pipes, regular circles (o) represent pipes with no heating. Dashed line is location of groundwater divide. Large circles with an (X) are the location of nested piezometers. Arrows are direction of surface water flow.

\subsection{DOC sampling protocol}

For each sampling date, duplicate samples of DOC concentrations were collected from five depths, $-20,-40,-60,-90$, and $-100 \mathrm{~cm}$ and from the surface. Water samples were collected from nested mini-piezometers (Freeze and Cherry [21]) located within the control and treatment blocks. DOC determinations were performed on a Tekmar Dohrmann ${ }^{\mathrm{TM}}$ Phoenix 8000 UV-persulfate oxidation TOC analyzer.

\subsection{Statistical analyses}

All data were analyzed using JMP-start statistics software, (SAS Institute Inc.). A Shapiro-Wilks W-test of normality was used to test for homogeneity of variances (Zar [22]). DOC and temperature data were analyzed using two-way analysis of variance (ANOVA). The response variables (DOC and temperature) were compared with the predictor variables of depth, season, control and treatment blocks, and pre-manipulation and manipulation collections. To determine differences among depths and seasons Tukey-Kramer HSD comparison tests were conducted. Winter seasons included December and 
February collections, spring consisted of April collections, summer included June and August collections, with fall including October collections. Stepwise regression analyses were conducted on the response variable (DOC) to 9 predictor variables (total phosphorus $\left.\mathrm{O}-\mathrm{PO}_{4}{ }^{3-}, \mathrm{mg} / \mathrm{l}\right)$, nitrate $\left(\mathrm{NO}_{3}-\mathrm{N}, \mathrm{mg} / \mathrm{l}\right.$ ), ammonia $\left(\mathrm{NH}_{3}-\mathrm{N}, \mathrm{mg} / \mathrm{l}\right)$, sulfide $\left(\mathrm{S}^{2-}, \mathrm{mg} / \mathrm{l}\right)$, dissolved oxygen (DO, $\left.\mathrm{mg} / \mathrm{l}\right)$, conductivity $(\mu \mathrm{S}), \mathrm{pH}$, total dissolved solids (TDS), and temperature $\left({ }^{\circ} \mathrm{C}\right)$.

\section{Results}

\subsection{Temperature data: pre-manipulation}

Temperature showed no statistical difference for all depths between control and treatment sites during the pre-manipulation. Fall and winter temperatures were most uniform among depths compared with spring and summer. Fall and winter temperatures increased with depth with fall values ranging from $12.6 \pm 0.3 \mathrm{SD}$ to $13.2 \pm 0.3{ }^{\circ} \mathrm{C}$ and winter values ranging from $7.4 \pm 0.3$ to $8.0 \pm 0.3{ }^{\circ} \mathrm{C}$ at -20 and $-100 \mathrm{~cm}$, respectively. In contrast, spring and summer temperatures decreased with depth. Spring temperatures ranged from $8.2 \pm 0.3$ at $-20 \mathrm{~cm}$ to $6.3 \pm 0.3{ }^{\circ} \mathrm{C}$ at $-100 \mathrm{~cm}$ and summer temperatures at $-20 \mathrm{~cm}$ ranged from $14.3 \pm 0.3$ to $12.9 \pm$ $0.3{ }^{\circ} \mathrm{C}$ at $-100 \mathrm{~cm}$.

\subsection{Temperature data: manipulation}

Temperature showed statistical differences between control and treatment blocks during the experimental manipulation. Temperatures between control and treatment blocks were significantly different for each depth in each season $(\mathrm{p}<0.0001, \mathrm{n}=468, \mathrm{~F}=2314.5)$. In winter, mean temperature for the control at $-20 \mathrm{~cm}$ was $7.9 \pm 0.1{ }^{\circ} \mathrm{C}$, compared with $11.9 \pm 0.1{ }^{\circ} \mathrm{C}$ for the treatment, an average difference of $4{ }^{\circ} \mathrm{C}$, fig. 2 . In winter, temperature differences between control and treatment plots were slightly higher with depth. At $-40 \mathrm{~cm}$ the control was $9.5 \pm 0.1{ }^{\circ} \mathrm{C}$ and the treatment was $14.6 \pm 0.1{ }^{\circ} \mathrm{C}$, a difference of $5.1{ }^{\circ} \mathrm{C}$. Differences between control and treatment at $-60,-80 \mathrm{~cm}$, and $-100 \mathrm{~cm}$ were $5.5,5.5$, and $4.9^{\circ} \mathrm{C}$, respectively, fig 2 .

Spring, summer, and fall temperature differences between control and treatment blocks also varied with depth. Differences at $-20 \mathrm{~cm}$ for spring, summer, and fall were $3.2,3.3$, and $3.3{ }^{\circ} \mathrm{C}$, respectively. At $-40 \mathrm{~cm}$, differences were 4.1, 4.1, and 4.0 for spring, summer, and fall, respectively. At $-60,-80$, and $-100 \mathrm{~cm}$, differences were also close among seasons; $-60 \mathrm{~cm}$ differences were $4.3,4.3$, and $4.0{ }^{\circ} \mathrm{C}$, at -80 all were 4.2 , and at $-100 \mathrm{~cm}$ differences were 3.7 , 3.5 , and $3.7^{\circ} \mathrm{C}$. In fall, highest temperatures for the treatment block were 18.6 and $18.7^{\circ} \mathrm{C}$ at -80 and $-100 \mathrm{~cm}$, respectively.

\subsection{DOC concentration patterns: pre-manipulation}

There was no significant difference in DOC concentrations between control and treatment blocks for surface and subsurface pre-manipulation collections. 
However, seasonal patterns were detected for most collection sites. Premanipulation concentrations of DOC at the surface were significantly higher in spring $(4.17 \pm 0.63 \mathrm{SD} \mathrm{mg} / \mathrm{l})$ compared with summer $(1.21 \pm 0.27 \mathrm{mg} / \mathrm{l})$, fall $(1.35 \pm 0.40 \mathrm{mg} / \mathrm{l})$, and winter $(1.51 \pm 0.30 \mathrm{mg} / \mathrm{l} ; \mathrm{p}=0.002, \mathrm{n}=3, \mathrm{~F}=6.43$; fig. 3A).

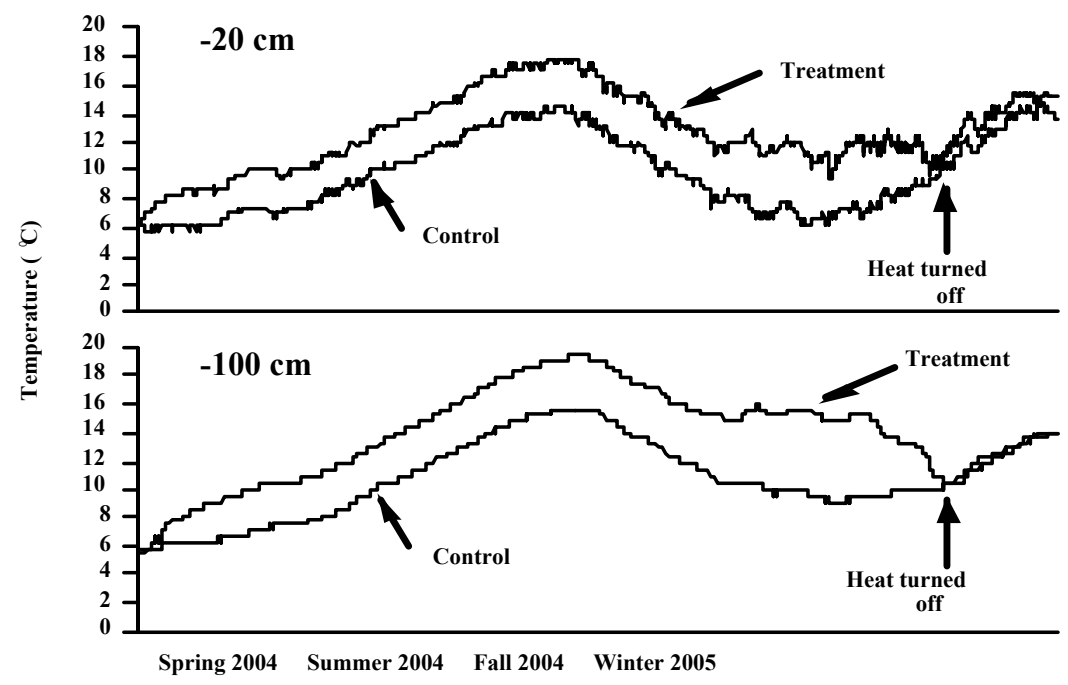

Figure 2: Temperature $\left({ }^{\circ} \mathrm{C}\right)$ at -20 and $-100 \mathrm{~cm}$ sediment depths, for control and treatment blocks during the heat-manipulation phase. Heat was turned off on 5 May 2005.

Furthermore, seasonal patterns during the pre-manipulation collections were not consistent with depth. At $-20 \mathrm{~cm}$, winter DOC was significantly lower $(3.48$ $\mathrm{mg} / 1 \pm 0.31 \mathrm{SE})$ than spring $(5.28 \pm 0.68)$, summer $(4.75 \pm 0.30 \mathrm{mg} / \mathrm{l})$, and fall $(4.60 \pm 0.37 \mathrm{mg} / \mathrm{l})$ concentrations $(\mathrm{p}=0.016, \mathrm{n}=3, \mathrm{~F}=3.91$; fig. $3 \mathrm{~A})$. At -40 $\mathrm{cm}$, spring and summer DOC concentrations were significantly higher than both fall and winter $(\mathrm{p}<0.0001, \mathrm{n}=3, \mathrm{~F}=10.60)$. Spring and summer DOC were $5.18 \pm 0.58 \mathrm{mg} / \mathrm{l}$ and $5.24 \pm 0.29 \mathrm{mg} / \mathrm{l}$, respectively, compared with $3.77 \pm 0.37$ $\mathrm{mg} / \mathrm{l}$ for fall and $3.06 \pm 0.30 \mathrm{mg} / \mathrm{l}$ for winter. In contrast, seasonal trends were not significant for the -60 and $-80 \mathrm{~cm}$ depths. Mean DOC concentrations at -60 $\mathrm{cm}$ ranged from a low of $4.22 \pm 0.57 \mathrm{mg} / \mathrm{l}$ in winter to a high of $6.46 \pm 0.91 \mathrm{mg} / \mathrm{l}$ in spring, and at $-80 \mathrm{~cm}$, DOC concentrations ranged from a low of $4.36 \pm 0.34$ $\mathrm{mg} / \mathrm{l}$ in winter to a high of $5.52 \pm 0.30 \mathrm{mg} / \mathrm{l}$ in spring. However, at $-100 \mathrm{~cm}$ seasonal trends were similar to -20 and $-40 \mathrm{~cm}$. Spring, summer, and fall DOC concentrations were all higher and significantly different from winter concentrations $(\mathrm{p}=0.0003, \mathrm{n}=3, \mathrm{~F}=7.73)$. 


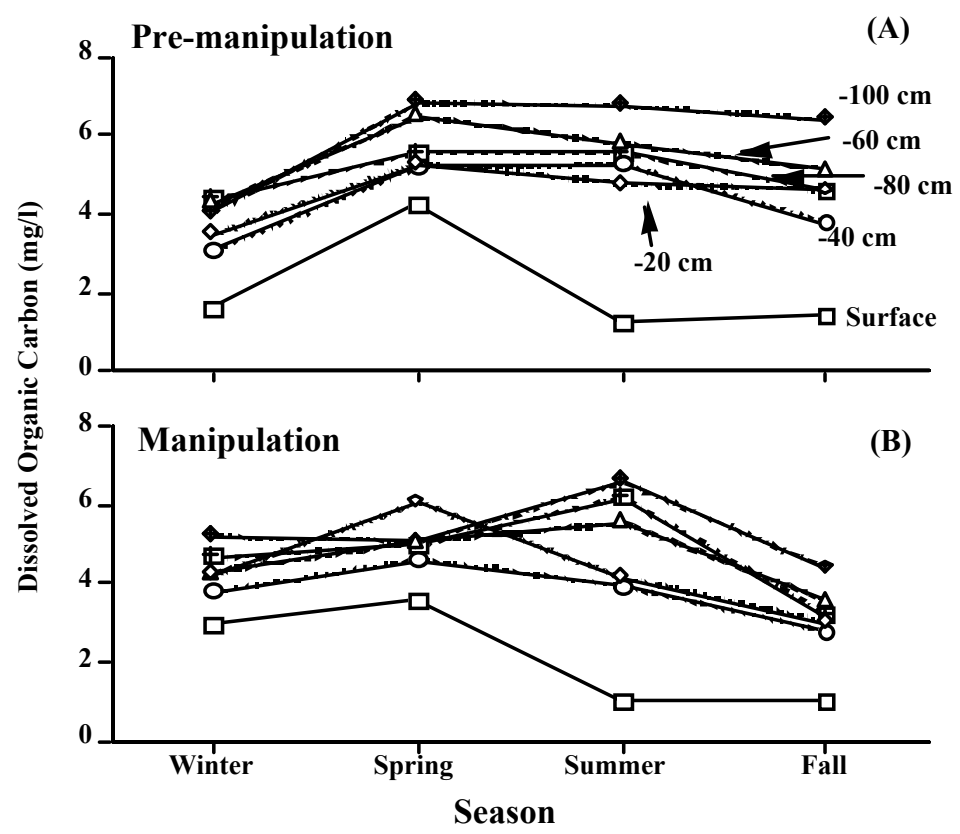

Figure 3: $\quad$ Seasonal concentrations of dissolved organic carbon (DOC, mg/l) for (A) pre-manipulation and (B) manipulation collections.

\subsection{DOC concentration patterns: manipulation}

Increased experimental temperatures did not have a significant statistical effect overall between control and treatment blocks. However, manipulation collections showed similar patterns to pre-manipulation collections. Similar to premanipulation collections, surface DOC concentrations were highest in the spring $(3.56 \pm 0.08 \mathrm{mg} / \mathrm{l})$ and significantly different from winter $(2.95 \pm 0.08 \mathrm{mg} / \mathrm{l})$, summer $(1.03 \pm 0.10 \mathrm{mg} / \mathrm{l})$, and fall $(1.00 \pm 0.11 \mathrm{mg} / \mathrm{l} ; \mathrm{p}<0.0001, \mathrm{n}=3$, $\mathrm{F}=213.84$; fig. 3B). However, different patterns were detected at several subsurface depths. At $-20 \mathrm{~cm}$, spring showed the highest DOC levels $(6.09 \pm$ $0.28 \mathrm{mg} / \mathrm{l})$ which were significantly different from winter $(4.25 \pm 0.28 \mathrm{mg} / \mathrm{l})$, summer $(4.18 \pm 0.28 \mathrm{mg} / \mathrm{l})$, and fall $(3.05 \pm 0.40 \mathrm{mg} / \mathrm{l} ; \mathrm{p}<0.0001, \mathrm{n}=3$, $\mathrm{F}=15.27$ ). In contrast with pre-manipulation results, manipulation patterns from -40 to $-100 \mathrm{~cm}$ showed statistical differences. At $-40 \mathrm{~cm}$, DOC concentrations for spring, summer, and winter seasons were highest and significantly different from the fall $(\mathrm{p}=0.27, \mathrm{n}=3, \mathrm{~F}=3.64)$. Seasonal patterns during the manipulation were also detected at -60 and $-80 \mathrm{~cm}$ unlike premanipulation collections. At $-60 \mathrm{~cm}$, fall was significantly different from the other seasons ( $p=0.010, n=3, F=4.69$; Table 1). In contrast, at -80 and -100 $\mathrm{cm}$, summer DOC concentrations were significantly higher $(6.21 \pm 0.35 \mathrm{mg} / \mathrm{l}$, and $6.61 \pm 0.35 \mathrm{mg} / \mathrm{l}$, respectively) than fall $(3.22 \pm 0.5 \mathrm{mg} / \mathrm{l}, 4.41 \pm 0.51 \mathrm{mg} / \mathrm{l}$, 
respectively; $\mathrm{p}=0.005, \mathrm{n}=3, \mathrm{~F}=8.44)$, whereas winter and spring concentrations were similar at these depths.

Although, there were no statistically significant differences between control and treatment blocks detected during the manipulation, a positive trend was detected. At $-20,-40$, and $-60 \mathrm{~cm}$, DOC concentrations were slightly higher in the treatment block compared with the control block. Differences between control and treatment block concentrations were 4.3 to $4.7 \mathrm{mg} / 1$ at $-20 \mathrm{~cm}, 3.7$ to $4.2 \mathrm{mg} / \mathrm{l}$ at $-40 \mathrm{~cm}$, and 4.5 to $5.1 \mathrm{mg} / \mathrm{l}$ at $-60 \mathrm{~cm}$. Positive increases in DOC concentrations were $0.4 \mathrm{mg} / 1,0.5 \mathrm{mg} / 1$, and $0.6 \mathrm{mg} / 1$ for $-20,-40$, and $-60 \mathrm{~cm}$, respectively, for all manipulation collections combined. However, this trend was not detected at -80 and $-100 \mathrm{~cm}$.

\subsection{Stepwise regression: pre-manipulation and manipulation}

The response variable DOC was analyzed with several predictor variables (nutrients and water chemistry, $\mathrm{n}=9$ ) to examine which predictor(s) best explain DOC concentrations. Examining pre-manipulation data for all collections and depths combined, the highest $r^{2}$ was 0.36 for all predictors $(n=9)$. After examining all possible models, $\mathrm{NH}_{3}-\mathrm{N} \mathrm{mg} / \mathrm{l}$, total-phosphorus (TP, mg/l), and temperature $\left({ }^{\circ} \mathrm{C}\right)$ were the best predictors, $\mathrm{r}^{2}=0.33$. The same analysis using manipulation data (all collections and depths) had an $\mathrm{r}^{2}=0.31$ for all predictors. However, the best predictors for the manipulation period were $\mathrm{NO}_{3} \mathrm{mg} / 1, \mathrm{NH}_{4}$ $\mathrm{mg} / \mathrm{l}$, and total dissolved solids (TDS), with an $\mathrm{r}^{2}=0.27, \mathrm{n}=3$.

Interestingly, predictor variables explain more variation when examining individual depths. For example, at $-100 \mathrm{~cm}$ for the manipulation period, all predictors produce $\mathrm{r}^{2}=0.73, \mathrm{n}=9$. With the best model, including $\mathrm{NO}_{3}-\mathrm{N} \mathrm{mg} / \mathrm{l}$, $\mathrm{NH}_{3}-\mathrm{N} \mathrm{mg} / \mathrm{l}, \mathrm{pH}$, and TDS, $\mathrm{r}^{2}=0.71, \mathrm{n}=4$.

\section{Discussion}

Surface concentrations of DOC were temporally variable during the premanipulation and manipulation study periods. Highest seasonal DOC concentrations at the surface occurred in spring compared with other seasons, fig 3A, 3B. A similar pattern was detected in an alpine catchment in Colorado, U.S.A. Boyer et al. [23] determined that during spring snowmelt, stream DOC concentrations increased and were highest (approximately $4.5 \mathrm{mg} / \mathrm{l}$ ) during this time compared with the rest of the year. The primary source of increasing DOC concentrations in spring was attributed to subsurface flow of water through soils in the Deer Creek catchment (Boyer et al. [23]). In contrast, Bernal et al. [24], determined that surface DOC concentrations were highest in a transition period, dry to wet (September to November, our fall season), and lowest in a wet and dormant period (December to February, our winter) and a vegetated period (March to May, our spring). In the Bernal et al. study [24], seasonal differences may be attributed to the study having been conducted in an intermittent Mediterranean stream with autochthonous and allochthonous carbon sources being available at different times of the year. 
Shallow groundwater $(-20$ to $-100 \mathrm{~cm})$ concentrations of DOC below the Valley Spring streambed were more seasonally variable than surface concentrations. Seasonal pre-manipulation and manipulation concentrations of DOC in the subsurface were always higher $(3-7 \mathrm{mg} / \mathrm{l})$ than the surface $(<4.2$ $\mathrm{mg} / \mathrm{l}$ ), fig. 3. Highest subsurface DOC concentrations were also during spring and summer, fig 3A, 3B. Rutherford and Hynes [25] sampled DOC from three agriculturally impacted Ontario streams from the surface to a depth of $-140 \mathrm{~cm}$. Variations in DOC concentrations were highly variable with depth and over time. Concentrations were typically higher at the surface and at $-20 \mathrm{~cm}$, but some stations had higher concentrations at the deepest depths $(-140 \mathrm{~cm})$ than intermediate depths ( -40 to $-60 \mathrm{~cm}$; Rutherford and Hynes [25]). Kaplan and Newbold [26] determined from the literature that concentrations of DOC in shallow groundwater can either decrease or increase with depth. These patterns are suggested to be due to extensive abiotic and biotic processing of terrestrial DOC sources in the vadose zone (zone of water limited above by the land surface and below by the water table) creating low phreatic zone DOC levels, whereas high phreatic zone DOC implies the opposite, low processing rates (Kaplan and Newbold [26]).

Temperature differences between the control and treatment blocks during the temperature manipulation were successfully maintained. The spring through fall difference, combining all depths, was $3.9 \pm 0.5 \mathrm{SD}{ }^{\circ} \mathrm{C}$, and combining all depths in winter the difference was, $5.0 \pm 0.6^{\circ} \mathrm{C}$, fig. 1 . Although targeted temperatures were reached, no significant differences in DOC concentrations were found between control and treatment blocks. Thus, our first of two predictions that no change in DOC concentrations would occur was supported. There could be a couple of reasons for this. Firstly, DOC concentrations in aquatic environments, especially in hyporheic and shallow groundwater ecosystems can be very heterogeneous. For example, Pabich et al. [27] examined DOC concentrations below the water table of a shallow estuary on Cape Cod, U.S.A. DOC concentrations of shallow groundwater were spatially variable, but temporally stable suggesting that local heterogeneity plays an important role in DOC delivery to shallow groundwaters (Pabich et al. [27]). Rutherford and Hynes [25] also suggest that the heterogeneity of DOC concentrations may be due to the complex flow patterns of hyporheic zones, and the typically mixed nature of bed sediments. Our data also suggest that subsurface DOC concentrations are heterogeneous due to the spatial and temporal variability in our system, thus possibly masking temperature-induced differences, fig. 3B. Secondly, the molecular structures that make up DOC are varied and highly complex. DOC is usually categorized into two main groups, non-humic or labile substances and humic substances (Wetzel [7]). Our study site is located in a temperate forest in southern Ontario, Canada. Such headwater streams are typically characterized by plant matter that accumulates after leaf-drop in the fall. Humic substances form most $(70-80 \%)$ of the organic matter in soils and water, are structures with highmolecular-weight (HMW) and are typically the result of microbial activity on plant material (Wetzel [7]). Humic substances released from leaves may decrease turnover rates of DOC and provide a continuous supply of DOC to the shallow 
groundwater ecosystem of Valley Spring. Further, since humic substances are recalcitrant to biological activity and tend to have low turnover rates, the effects of increased metabolic activity on DOC concentrations under the increased thermal regime induced in Valley Spring may not have been detectable over the short time period of $13 \mathrm{mo}$. In contrast, labile DOC typically consists of carbohydrates, proteins, amino acids, and other low molecular weight (LMW) substances. These LMW substances are readily used by microorganisms, creating conditions for rapid flux in aquatic ecosystems.

Manipulation concentrations of DOC were correlated most with $\mathrm{NO}_{3}-\mathrm{N} \mathrm{mg} / \mathrm{l}$, $\mathrm{NH}_{3}-\mathrm{N} \mathrm{mg} / \mathrm{l}$, and total dissolved solids (TDS), $\mathrm{r}^{2}=0.27, \mathrm{p}<0.0001, \mathrm{n}=3$. DOC was positively correlated with ammonia, both concentrations increased with depth, and DOC was negatively correlated with nitrate; DOC concentrations increased with depth while nitrate concentrations decreased. This shows a tight coupling between DOC and nitrate and ammonia. For example, if there are small changes in DOC concentrations there is the possibility on non-linear effects on watershed $\mathrm{N}$ retention (Goodale et al. [28]). These latter authors examined the spatial patterns of nitrate and DOC concentrations of 100 northeastern U.S. streams, and showed that as DOC concentrations increase, nitrate concentrations decrease.

Our study did not see a change in DOC concentrations under a simulated global warming experiment, although a trend of slightly higher DOC concentrations was detected in the treatment block. We advocate that further large-scale ecosystem manipulations should be conducted to more fully understand the role and transformations of DOC in streams and shallow groundwaters. In particular, these studies should examine the molecular fractions or species of DOC, in order to detect changes in allochthonous and autochthonous sources (e.g. Sachse et al. [29], Sobczak and Findlay [30]). For example, it has been shown that allochthonous DOC is the most important determinant of thermocline depth in small boreal lakes (PerezFuentetaja et al. [31]). Further, if the type of DOC entering such aquatic systems is not known (allochthonous verse autochthonous) correct management policy decisions may be very difficult to make.

\section{References}

[1] Fisher S.G. \& Likens G.E., Energy Flow in Bear Brook, New Hampshire: an integrative approach to stream metabolism. Ecological Monographs 43(4), pp. 421-439, 1973.

[2] Hynes, H.B.N., The stream and its valley. Internationale Vereinigung fur Theoretische und Angewandt Limnologie, 9(1), pp. 1-15, 1983.

[3] Chapelle, F.H., Ground-water microbiology and geochemistry, John Wiley \& Sons, Inc.: New York, pp. 263, 2001.

[4] Williams D. D. \& Hynes H.B.N., The occurrence of benthos deep in the substratum of a stream. Freshwater Biology, 4(1), pp. 233-256, 1974. 
[5] Meyer J.L. \& Tate C.M., The effects of watershed disturbance on dissolved organic carbon dynamics of a stream. Ecology, 64(1), pp. 3344, 1983.

[6] Storey, R.G., Howard, K.W.F. \& Williams, D.D., Factors controlling riffle-scale hyporheic exchange flows and their seasonal changes in a gaining stream: A three-dimensional groundwater flow model. Water Resources Research, 39(2), pp. 2003.

[7] Wetzel, R.G., Limnology: Lake and River Ecosystems, Academic Press: San Diego, pp. 735, 2001.

[8] Pace, M.L. \& Cole, J.J., Synchronous variation of dissolved organic carbon and color in lakes. Limnology and Oceanography, 47(2), pp. 333-342, 2002.

[9] Schindler, D.W., The cumulative effects of climate warming and other human stresses on Canadian freshwaters in the new millennium. Canadian Journal of Fisheries and Aquatic Sciences, 58(1), pp. 18-29, 2001.

[10] Hengeveld, H.G., Projections for Canada's climate future. Environment Canada Document CCD 00-01, pp. 1-27, 2000.

[11] Sweeney, B.W., Bioenergetic and developmental response of a mayfly to thermal variation. Limnology and Oceanography, 23(2), pp. 461-477, 1978.

[12] Vannote R.L \& Sweeney B.W., Geographic analysis of thermal equilibria: a conceptual model fro evaluating the effects of natural and modified thermal regimes on aquatic insect communities. The American Naturalist, 115(5), pp. 667-695, 1980.

[13] McCarty J.P., Ecological consequences of recent climate change. Conservation Biology, 15(2), pp. 320-331, 2001.

[14] MacDonald N.W., Randlett, D.L. \& Zak, D.R., Soil warming and carbon loss from a lake states spodosol. Soil Science Society of America Journal, 63(1), pp. 218-221, 1999.

[15] Pastor, J., Solin, J., Bridgham, S.D., Updergraff, K., Harth, C., Weishampel, P. \& Dewey, B., Global warming and the export of dissolved organic carbon from boreal peatlands. Oikos, 100(2), pp. 380386, 2003.

[16] Neff, J.C. \& Hooper, D.U., Vegetation and climate controls on potential $\mathrm{CO}_{2}$, DOC and DON production in northern latitude soils. Global Change Biology, 8(9), pp. 872-884, 2002.

[17] Schindler, D.W., Bayley, S.E., Parker, B.R., Beaty, K.G., Cruikshank, D.R., Fee, E.J., Schindler, E.U. \& Stainton, M.P., The effects of climatic warming on the properties of boreal lakes and streams at the Experimental Lakes Area, northwestern Ontario. Limnology and Oceanography, 41(5), pp. 1004-1017, 1996.

[18] Clair, T.A., Arp, P., Moore, T.R., Dalva, M. \& Meng, F.R., Gaseous carbon dioxide and methane, as well as dissolved organic carbon losses from a small temperate wetland under a changing climate. Environmental Pollution, 116(1), pp. S143-S148, 2002. 
[19] Williams D.D. \& Hogg I.D., The ecology and production of invertebrates in a Canadian coldwater spring. Holarctic Ecology, 11(1), pp. 41-54, 1988.

[20] Hogg, I.D. \& Williams, D.D., Response of stream invertebrates to a global-warming thermal regime: An ecosystem-level manipulation. Ecology, 77(2), pp. 395-407, 1996.

[21] Freeze, R.A. \& Cherry J.A., Groundwater, Prentice-Hall, Inc.: New Jersey, pp. 23-24, 1979.

[22] Zar J.H., Biostatistical Analysis, Prentice Hall: New Jersey, pp. 88-89, 1999.

[23] Boyer, E.W., Hornberger, G.M., Bencala, K.E. \& McKnight, D.M., Response characteristics of DOC flushing in an alpine catchment. Hydrological Processes, 11(12), pp. 1635-1647, 1997.

[24] Bernal, S., Butturini, A. \& Sabater, F., Seasonal variations of dissolved nitrogen and DOC: DON ratios in an intermittent Mediterranean stream. Biogeochemistry, 75(2), pp. 351-372, 2005.

[25] Rutherford, J.E. \& Hynes, H.B.N., Dissolved organic carbon in streams and groundwater. Hydrobiologia, 154(1), pp. 33-48, 1987.

[26] Kaplan, L.A. \& Newbold, J.D., Surface and subsurface dissolved organic carbon (Chapter 10). Streams and Ground Waters, ed. J.B. Jones \& Mulholland P.J., Academic Press: San Diego, pp. 237-253, 2000.

[27] Pabich, W.J., Valeila, I. \& Hemond, H.F., Relationship between DOC concentration and vadose zone thickness and depth below water table in groundwater of Cape Cod, U.S.A. Biogeochemistry, 55(3), pp. 247-268, 2001.

[28] Goodale, C.L., Aber, J.D., Vitousek, P.M \& McDowell, W.H., Long-term decreases in stream nitrate: Successional causes unlikely; Possible Links to DOC? Ecosystems, 8(3), pp. 334-337, 2005.

[29] Sachse, A., Henrion, R., Gelbrecht, J. \& Steinberg C.E.W., Classification of dissolved organic carbon (DOC) in river systems: Influence of catchment characteristics and autochthonous processes. Organic Geochemistry, 36(6), pp. 923-935, 2005.

[30] Sobczak, W.V. \& Findlay, S., Variation in bioavailability of dissolved organic carbon among stream hyporheic flowpaths. Ecology, 83(11), pp. 3194-3209, 2002.

[31] Perez-Fuentetaja A., McQueen D.J. \& Ramcharan C.W., Predator-induced bottom-up effects in oligotrophic systems. Hydrobiologia, 317(2), 163$176,1999$. 